\title{
NEW AND OLD APPROACHES TO THE PHENOMENOLOGY OF PAIN ${ }^{1}$
}

Agustín Serrano de Haro (Instituto de Filosofía, CSIC/Madrid)

\begin{abstract}
Ortega y Gasset's old lament that no one had so far attempted a rigorous phenomenology of pain no longer holds since the appearance of Christian Grüny's recent monograph Zerstörte Erfahrung. Eine Phänomenologie des Schmerzes. Grüny argues for the use of phenomenological categories from Merleau-Ponty in order to understand physical pain as a "blocked escape-movement" ("blockierte Fluchtbewegung"), concluding that corporeal suffering makes impossible both a clean distinction and a pure identification between the lived body and the physical body that I am. In my paper, I would like to suggest some improvements in Grüny's approach through the utilization of the category of self-affection, as the material phenomenology of Michel Henry has developed it. In addition to the radical immanence, in which hyle, noesis, and noema are unified into a "carnal cogito", however, I argue that it is necessary to describe the painful self-affection not only in terms of a sensitive excess whatever (überhaupt), as Grüny posits, but also in terms of a mutation of the sensitive excess into the intra-tactile sphere of sensibility. Thus I endorse the Husserlian insight that makes tactility the primordial structure of sensibility.
\end{abstract}

Keywords: Pain, phenomenology, blocked movement, self-affection.

1. A series of lectures under the title of "Man and People" were presented from 1949 to 1950 by the Spanish philosopher José Ortega y Gasset in Madrid, not actually in the University, where his voice had not been heard since 1936, but in a crowded theater. With the passing of time, this informal course became the ultimate witness to the remarkable strength and depth of the reception of phenomenology in Spain before the Civil War (1936-1939). In this course, Ortega attempted a brave and renewed approach to the discussion of human intersubjectivity as it springs from one's own life's radical immanence. It was in this framework that the seventh lecture made an explicit reference to the untransferable experience of physical pain, only one's own, in terms that remain surprisingly appealing to phenomenologists even today. Ortega's exact words were:

\footnotetext{
${ }^{1}$ I am highly indebted to George Heffernan for his constant help with the English version of my paper.
} 
I cannot now enter into a strict phenomenology of pain-which, by the way, no one has undertaken-but it would show that our pains, which are one of the things found in the world of each of us, our subjective world, have a positive dimension in virtue of which, at the same time that they exasperate us, we feel for them something rather like affection, the diffuse but warm attitude, we might call it, that we feel towards everything that is genuinely ours. And this is because while it pains us it is intimate to us. How could it be otherwise, if in pain it is always I who suffer the pain? I say this merely to give an extreme example, in order to contrast with it what happens to us in the case of the objective or common world in which we live with other men and which is what we normally call the World, and even, if you like, the real World ${ }^{2}$.

Two motives or aspects, quite peculiarly intertwined, may strike the reader's attention in this old quotation from Ortega. What stands out, first of all, is his lucid lament, not because of pain, but because of the lack of "a strict phemonenology of pain". Such a phenomenological inquiry has not been undertaken yet -he states, surely unaware of Buytendijk's incomplete attempt in $1943^{3}-$, whereas to submit the experience of physical pain to an immanent analysis has to be possible, almost on principle. But what I also find remarkable in Ortega's brief sketch concerning pain is an air of conceptual affinity to Michel Henry's later philosophy. The statement that "in pain it is always I who suffer the pain" -in a translation a bit keener: "in pain I am always the one who undergoes pain within myself"- evokes immediately the category of immanent self-affection. This central concept of Henry's material phenomenology is also recognizable in the role of pain as a paradigm of one's subjective world, separated from the objective world of common reality. Both motives, the lament on the missing phenomenology of pain and the sketch resembling Henry's later theory, clearly different as they are, converge in my paper in a way I would like to begin by outlining.

Ortega's words were pronounced in 1950, half a century after the emergence of phenomenology in the intellectual world. And another fifty years have had to pass before we could say that such a phenomenology of pain has been rigorously and exhaustively attempted. In 2004, the German thinker, Christian Grüny, an outstanding follower of Bernhard Waldenfels, published his work Zerstörte Erfahrung (Destroyed Experience), whose subtitle states precisely: Eine Phänomenologie des Schmerzes (A

${ }^{2}$ J. ORTEGA Y GASSET, Man and People, English trans. by Willard R. Trask, London: Allen \& Unwin, 1957, p. 141. I have slightly modified the translation.

${ }^{3}$ Originally appeared in Dutch. A German translation was already published in 1948, in Bern: Über den Schmerz. 
Phenomenology of Pain $)^{4}$. In fact, the book represents an ambitious analysis, both descriptive and conceptual, of the pain that our body suffers in its own flesh. Grüny departs from the fact that physical pain is an experience that has been neglected in the history of thought or, even better, a whole complex of experiences that has been scarcely analyzed even in those philosophical systems which, from Epicurus to Schopenhauer, granted pain a major role in their theoretical worldviews. Even more surprising is the finding that phenomenology itself, or at least "classical phenomenology", "largely took shelter" from this dramatic and yet quite common experience ${ }^{5}$. Such a situation amounts to the paradox that, concerning the understanding of pain, physicians who think in a philosophical way have been more fruitful than philosophical scholars, who do not heal. Nevertheless, Grüny's understanding of pain is largely and explicitly based on the thought of Merleau-Ponty, and especially on Phénoménologie de la perception. Notwithstanding that Merleau-Ponty only occasionally paid attention to physical pain, and mostly only as an example, his treatment of the lived body would entail for this topic a relevance that to a certain extent encounters no competition among phenomenologists, either classic or postclassic ${ }^{6}$.

In my paper, I would like to make a presentation of this recent and truly important phenomenology of pain. But my personal point of view also takes advantage of the second aspect of Ortega's quotation, in that I suggest that the category of immanent self-affection, of a self-affective pathos, remains fruitful even if one accepts the core of Grüny's description of pain. Whereas perception is rarely self-perception, desire is not always self-desire, and joy is not in principle the joy of one's self, pain is indeed a sort of self-twisting, so that with an ache it is actually I who "aches myself". Furthermore, there is a second, so to speak, pre-Henrinian, element in Ortega's view, namely, that enigmatic duality, in virtue of which the same pain that exasperates us, and that can, with no mercy, subjugate us, may have a positive dimension engendering something similar to a warm affection, a renewed fondness towards oneself. Such a union of contraries surely reminds us of the primordial rhythm of self-affection, which,

\footnotetext{
${ }^{4}$ Würzburg: Königshausen \& Neumann.

${ }^{5}$ C. GRÜNY, Zerstörte Erfahrung, p. 13. All translations are mine.

${ }^{6}$ In drawing so deeply on Merleau-Ponty for a phenomenology of suffering, Grüny has followed the path cleared before him by Drew Leder in The Absent Body and explored after him by Abraham Olivier in Being in Pain.
} 
according to the "material phenomenology" of decades afterwards, makes suffering and joy go hand in hand, and in the end enables life's joyful parousia to pervade even physical pain. Against this underlying union, Grüny underlines quite convincingly the negative, harmful condition of pain, which, in the case of acute or chronic pain, or in that of torture, may even destroy life-experience from within; in such extreme cases, pain turns out to be the actual experience of the destruction of experience itself. Thus, in the final part of my paper I will outline how such an immanent but harmful selfaffection may be illuminated with the help of some old phenomenological categories to be found in the Husserlian analysis of the lived-body and of its primal constitution in the tactile sphere of sensibility. In any case, what is at stake throughout these new and old approaches to the phenomenology of pain is not an internal debate between current and past phenomenologists, but an open theoretical undertaking of remarkable relevance for human experience. Therefore, I would prefer to finish my introduction here and to proceed "to the things themselves" immediately.

2. Grüny's approach to physical pain begins with an update of Merleau-Ponty's criticism of the theory of sensations as the lowest material of conscious life. As a matter of fact, in the philosophical tradition bodily pain has been overwhelmingly treated as a sense-datum, as a specific kind of sensed quality, as subjective qualia. In this respect, and despite having one foot in this pre-conception and the other one in a new understanding, the Husserl of the Logische Untersuchungen or Ideen I or the Scheler of Der Formalismus would still belong to this tradition and, therefore, they would assume a hyletic notion of the experience of pain, without further intentional relevance. But the narrow notion of hyle, of the sense-datum, never manages to escape from the dilemma of either (1) turning bodily pain into an atomic conscious quality, with only a special emotive feature -the Gefühlsempfindungen-, or (2), in case the harmful (nocent or nocive) factor and the physical localization of pain are admitted as basic elements, turning it into an objective term for a painless consciousness that objectifies it. And just like the general epistemological dilemma between empiricism and intellectualism, which Merleau-Ponty tries to overcome, we will either have a pure sensation, worldless and bodiless (empiricism), or we will have pain as an objective feature of an already objectified body 
(intellectualism). The powerful new alternative that Grüny offers consists of what he calls a "motoric physiognomy" of pain, that is, an articulate Gestalt of feeling, which, in a prereflexive way, modulates itself, thus also modulating the corporeal subjectivity that inhabits it, and consequently defining a suffering presence in and towards the world. Pain experience is certainly complex, but it is not composed of atomic underlying qualities, be they conscious or neurological, and therefore it resembles more an expressive gesture than a severed conscious content, and more a corporeal posture than an anonymous, physiological process. So let us explore some relevant features of this motoric physiognomy of pain as Grüny depicts it.

The irruption of pain adopts the profile of a disturbance of experience, a disruption in the normal continuity of subjective action in the life-world. In pain, the subject of experience itself is touched and reached (betroffen), hit upon as a target (getroffen). Before the ego acquires a representation, an interpretation or a conceptual grasp of the affection that has occurred, before it eventually manages to integrate the occurrence in its coping with the world, a crisis, not just a contrast, has already happened, and this crisis involves oneself -it traps one and forces one's attention. This factor of violence to the ego, this sort of aggression on it, not of mere affection of it (in which Grüny follows clearly Buytendijk`s precursory work), is closely related to the basic formula with which the German phenomenologist tries to obtain an essential description of pain. According to the rich developments of the book, pain turns out to be "a blocked movement of flight": eine blockierte Fluchtbewegung. And this formula has in a certain sense to be understood literally. Pain is always in process or ongoing -it is a motion (Regung), as Husserl would have put it. And this essential mobility of pain is characterized by the fact that its harming negativity finds no way out, but rather keeps on searching; it cannot be ignored, disconnected, deactivated, nor can it be accepted or integrated, it can only be suffered. And thus feeling pain seems like an unceasing aborted escape. In a single stroke, the negative, aversive condition that reaches the ego is given to one and is rejected by one, but in the same stroke the rejection gets blocked and stumbles, so to speak, upon itself. In other words, the motion in which physical pain consists is a retraction from what is doing the harming. It is incapable, however, of moving away, of withdrawing, since the same body, the same corporeal ego, hosts and lends reality to the affection that brings suffering upon one. Therefore, the flight has no exit, finds no possible direction of escape, and the movement is at the same time activated through aversiveness and blocked from within. 
According to Grüny, this is in fact what the sufferer lives or experiences as physical pain: an indivisible unity of a discharge reaching its target, with an aversive retraction away from it, and, in short, a continuous blocked movement. And it has to be noted that this peculiar structure provides a basic description of one's being in pain, of the exact instants of suffering, of the painful core of the experience. An instant later, or at the same time, the experience of pain is followed or faced by the movements of changing one's posture, of rubbing or caressing the spot that hurts, of soothing aid from one part of the body or from the whole body to that other in pain, etc. These are rather the intentional, kinesthesic movements with which the sufferer gives the first and basic reaction to his or her suffering, and hence their physiognomy is clearly different from that blocked movement that has come upon one, without one's permission and against one's purpose. Although Grüny does not use this expression, and although in fact he does not make any use at all of the basic notion of kinesthesis, the painful-blocked movement appears quite exactly as "a counterkinesthesis"7: a sheer subjective motion that one cannot shun, an anti-subjective movement that one undergoes.

3. Grüny's powerful inquiry, originally following Merleau-Ponty's thought and peculiarly deepening the dynamic condition of pain, deserves an unambiguous acknowledgment from a phenomenological standpoint. Yet the conceptual doubt as to whether in the understanding of the "blocked movement of flight" the key concept remains that of self-affection, conceived as a conscious self-pathetic experience of the subjective body, has still not been decided. Grüny tenaciously avoids this possibility and makes clear his categorical rejection of the way in which Michel Henry has argued for life's immanence as an intimate, absolute "self-embrace" -that is, a worldless self-affection-, which should be thought of as the ultimate origin of each and every phenomenon: "Therefore, the thesis of the following text is thoroughly opposed to the attempt of Michel Henry to conceive of pain as the paradigm of the worldless self-affection of a body

\footnotetext{
${ }^{7}$ Husserl uses this expression in a somewhat different sense, namely, to refer to the pressure on a limb of the body that therefore cannot be freely moved. See E. HUSSERL, Zur Phänomenologie der Intersubjektivität. Dritter Teil : 1929-1935, Husserliana XV, Den Haag: Martinus Nijhoff, 1973, p. 295.
} 
described as flesh" ${ }^{\prime 8}$. But, however legitimate the grounds of Henry's phenomenological extremism, always on the verge of an ontological monism, may be, I rather feel inclined to defend the position that an advanced phenomenology of pain, such as Grüny has promoted, does indeed call for the notion of self-affection and does indeed even require it. In the end, the painful motion seems to stem from the excessive affection that sensibility hosts in itself and that makes it suffer in an essentially mobile circle of simultaneous charge and discharge upon itself. In physical suffering, perceptive and bodily sensibility, which is normally opened to the world, reverts inwards, flows back, without any intentional exit, without a transitive vector to anything else, enclosed in a possibly unexpected revelation of itself. Now sensibility operates inwardly and grows full of itself in a non-reflective turn that is still an intimate twisting in virtue of which "I am always the one who undergoes suffering in myself", as Ortega put it. The Spanish language allows even the reflexive form: something like "I ache myself". So the two main features that characterize the notion of self-affection, according to Henry's material phenomenology, are clearly at the forefront. First, a pathos or passivity but in an all too mobile and immanent course, amounting to an internal unity of action and passion: I do not carry out the act of suffering nor do I guide it or unfold it, but rather I just assist it, I just suffer it from within, I am it. And, second, this motion that flows back is playing indistinctly the three main roles of the intentional correlation: pain is the subjective experience that I feel, it is the "object" that is experienced in it, and is the sensitive material at the base of the experience and of the object; the painful happening comes to be noted (noema) as soon as it is lived or suffered (noesis), and comes to exist as soon as it is hyletically supported. In Henry's words, physical suffering is a "carnal cogito", the perfect blending of sensibility and noetic as well as noematic terms.

As a sound follower of Waldenfels, Grüny dismisses Henry's assumption that the affectivity of the living being is at every moment a true joy of life; on the approach of material phenomenology, life's self-revelation ought to remain joyful even amidst severe suffering or in the depths of it; not even pain would be able to interrupt that intimate affection towards oneself to which Ortega's pre-Henrinian words referred and which proves to be, in the end, a sempiternal structure of happiness without possible contrary or breach. In the first two parts of his book, which are not yet concerned with the "ontological assault" of chronic pain or of totalized suffering in torture, Grüny already takes up a strong

\footnotetext{
${ }^{8}$ Zerstörte Erfahrung, p. 35.
} 
stance, and quite rightly in my opinion: he remains entirely faithful to the natural valuation of physical suffering, and therefore does not hesitate to declare pain's pathos as harming the sufferer, as preying upon his or her life. Such a distressing factor pertains to pain's sense, or, if you wish, it pertains to its lived and recognized lack of sense. If a supposed duality of layers in pain awareness, the first one purely informative sense-data and the other the affective-harmful sensations, lacks descriptive legitimacy, and hence Stumpf's or Scheler's or, more recently, Damasio's efforts are out of focus, then much weaker evidence is to be granted to a counter-descriptive view of harmful experience as the subtlest veil of joy. Yet this clear insight that self-affection need not be either joyful or worldless does not imply that the structure of physical suffering might be described without the immanent unity, altogether hyletic, noetic, and noematic, altogether passive and active, that self-affection entails.

So how can these two phenomenological motives, namely, the blocked movement of flight and the conscious self-affection, be united on an appropriate basis? How is one to conceive of an entirely immanent affection that carries out a breach of experience and that at the limit may yield a true destruction of experience? In my opinion, the union for which we are seeking requires us to take into account Husserl's old claim of a profound difference between all kinds of sensuous experiences whatever, on the one hand, and the tactile sensibility, on the other, or, in other words, between the visual, auditive, or in general presentive sensations, and the hyle related to the tactile field, and particularly to the intra-tactile field as the proto-constituting instance of the lived body. This duality, outlined in Ideas II and in a number of texts of Husserliana $\mathrm{XV}^{9}$, allows us to appreciate and at the same time to correct Grüny's general assumption that the whole spectrum of human sensibility is equally exposed to pain. In his own words: "any sensuous excess by which we are affected with a surplus of strength comes to be experienced as pain, no matter in which sensuous register the excess takes place" ${ }^{\prime 10}$. Whether it be an oppressive pressure, a burning focus, a prick on any part of one`s body, or, instead, a blinding light or a disturbing harmful noise that afflicts one, all these situations may equally fire up pain, in a highly homogeneous way, in a sort of universality. And therefore: "pain can thus be understood as the preponderance of the pathetic, without the need of recognizing in

\footnotetext{
${ }^{9}$ Cf. Zur Phänomenologie der Intersubjektivität, Hua. XV, pp. 277-281, 314-328, 648-656.

10 Zerstörte Erfahrung, p. 105: "Damit kann man auch das Phänomen zu fassen bekommen, dass jedes sinnliche Übermass, in dem wir zu stark «affiziert» werden, als Schmerz erfahren wird, egal in welchen sinnlichen Register es stattfindet".
} 
advance an underlying pain-sense existing by itself" ${ }^{11}$. Yet this convincing position may, and, in my opinion, should, be complemented by the principle that any sensuous phenomenon of whatever sort only then comes to be experienced as pain when its excess transmutes its data into tactile affection. Pain then appears when the sensuous data, in virtue of their surplus, mutate into another register, and this emerging phenomenon is always of an intra-tactile character. The famous example given by Bergson provides clear support in this respect: my perceptual contact with a pin changes into a painful prick by a gradual increase of pressure. At a certain point, the perception of the pin`s sharpness and hardness disappears, and it turns into a painful affection in my hand; the previous tactile perception, from which pain seemed to emanate as a higher degree, ceases altogether and is completely replaced, substituted for by an internal perception; no reports of the pin's acuteness, hardness or temperature remain, and the entire affair gets reconverted into a solely intra-tactile experience involving pain. Now, in the same vein, but mutatis mutandis, an aggressive light-dazzling or an afflictive uproar cease also to operate as visual or auditive phaenomena: in their excess, in virtue of it, they suddenly change their condition and twist inwardly, self-affectively. No longer is there only light or only noise that is intentionally offered to oneself, that is perceptively present. It is rather one's eyes or one's ears that come now to be felt and turn now to be given from within, in their intimate spatiality. While perceiving, I do not pay attention or co-attention to my eyes, which cooperate with my experience from a phenomenal absence. But when, as a result of what is visible, my eyes hurt me, drawing the main attention towards themselves, then not only does the panorama as seen change, as Sartre tried to argue, nor is it just a disturbance in my eyes that I happen to see. Rather, I come now to a sensuous awareness of my eyes, but in their sheer closeness, in their bodily condition, in their intimate tactile vibration, all of which are colorless. In this precise sense, the pathic or pathetic may indeed be related to any sensuous excess, as Grüny keenly posits, but the pathetic quality always has an intra-tactile contexture or constitution. Inner pains, unrelated to sensory fields, have only this second condition, without any external phenomena at their grounds. According first to the Greek and then to the German archaism that Husserl felt obliged to introduce, we would say that the sensibility defining physical pain is of a "haptic" character, for the painful self-affection

\footnotetext{
${ }^{11} \mathrm{Ibid}$ : "Der Schmerz kann so als Überwiegen des Pathischen verstanden werden, ohne dass vorab ein für sich bestehender Schmerzsinn unterstellt werden müsste".
} 
corresponds in principle to the intra-tactile, and therefore somaesthetic, "Empfindnisse", and not to the "Empfindungen". It is certainly remarkable that Husserl, who did not develop a phenomenology of pain, did indeed sketch this entirely basic principle in Ideas II: "Lived-body [Leib] can only be originally constituted as such in tactility, and in all that becomes localized with tactile sensations, such as heat, cold, pain, etc." ${ }^{12}$ In this way, the strict viewpoint of pain analysis seems to validate Welton's assessment that Husserl's treatment of tactile experience "integrates body and conscious life in a way never envisioned by the tradition of Western philosophy" ${ }^{\prime 3}$.

4. The conceptual analysis I have outlined is grounded, in short, in three successive considerations, which, stepping back from the new approaches in the phenomenology of pain to the older ones, preserve nevertheless a unitary description. Thus, the first step clearly assumes the core of Grüny's description, according to which pain experience is a sort of subjective movement, but a blocked one, a negative motion in a very positive sense, an adversity displayed in one's flesh, so that, at the same time, at the same stroke, it is hosted, rejected, and made unpleasantly real. In this sense, pain could give rise to the concept of, quite literally, a counter-kinesthesis: an anti-selfmovement. The second step advocates then for the category of immanent self-affection, as established in Henry's material phenomenology, in order explicitly to conceptualize such a phenomenological analysis. In this sense, the blocked movement flows in a radical closeness from itself against itself, and this movement is entirely self-appearing or self-revealing and is as conscious as it is bodily. The final step backwards suggests, in the end, an original third way, so to speak, between the all-embracing character of self-affection in Henry's phenomenology-to the extent that every corporeal movement and every subjective experience, not just pain or joy, are equally self-affective- and the complete absence of self-affection in Grüny's work-to the extent that pain is for him basically related to an excess of hetero-affection. Thus Husserl's treatment of different structures of sensibility and his proposal of a radical proto-structure in intimate tactility,

\footnotetext{
${ }^{12}$ Ideen zu einer reinen Phänomenologie und phänomenologischen Philosophie. Zweites Buch, Husserliana IV, Den Haag, Martinus Nijhoff, 1952, p. 150. (Italics added.)

${ }^{13}$ D. WELTON, "Soft, smooth hands: Husserl's Phenomenology of the Lived-Body", in D. WELTON (ed.), The Body; Classic and Contemporary Readings, Oxford: Blackwell, 1999, p.47.
} 
the only one which is primarily self-affective and endowed with a proper selfreferentiality, proves to be of great value for the understanding of pain. For a blocked movement is only possible as a tactile self-affection where body and consciousness blur into each other.

Let me now conclude by ironically confessing that the foregoing analysis was merely an introduction to the exact topic that I had in mind. Rather, my original purpose was to deal with the promising developments that genetic phenomenology may possibly provide for the analysis of physical pain. I was particularly interested in the unsurpassable limits to a phenomenological understanding of pain that Grüny empathically draws in the last part of his book, that is, in his examination of the dreadful totalization of pain in extreme or chronic suffering. There his argument is that both the phenomenological distinction as well as the relation between a lived body and a physical body come to fail in the face of the paradoxical materialization of the subjective body in pain and as pain. My hypothesis is, on the contrary, that such a fracture line of experience may be illuminated with the aid particularly of genetic phenomenology, as well as that the genetic reconstruction of intentionality is capable of tracing back the experience of incarnation to structures and strata that are prior to one's learning of things and hence to one's knowledge of one's own physical body as one of them-for "we have learned to experience things". However, we shall have to leave these truly difficult questions for another occasion.

Agustín Serrano de Haro

Instituto de Filosofía, CSIC

C/ Albasanz, 26-28

28037 Madrid

agustin.serrano@cchs.csic.es 


\section{BIBLIOGRAPHY}

Bergson, H., Matière et mémoire. Paris: PUF, 1939.

Buytendijk, F.J.J., Über den Schmerz. Übers. H. Plessner. Bern: Huber, 1948. (Pain: Its Modes and Functions. Trans. Eda O'Shiel. Chicago: University of Chicago Press, 1962.)

Damasio, A, Descartes' Error. Emotion, Reason and the Human Brain, New York: Putnam`s Sons, 1994.

García-Baró, M., Del dolor, la verdad y el bien. Salamanca: Sígueme, 2006.

Grüny, C., Zerstörte Erfahrung. Eine Phänomenologie des Schmerzes. Würzburg: Könighausen und Neumann, 2004.

Henry, M., Phénoménologie matérielle. Paris: PUF, 1990.

----, Incarnation. Une philosophie de la chair. Paris: Seuil, 2000.

Husserl, E., Ideen zu einer reinen Phänomenologie und phänomenologischen Philosophie, Zweites Buch. Husserliana IV. Den Haag: Martinus Nijhoff, 1952.

----, Zur Phänomenologie der Intersubjektivität, Dritter Teil: 1921-1928. Husserliana XIV. Den Haag: Martinus Nijhoff, 1973.

Leder, D., "Toward a Phenomenology of Pain", in The Review of Existential Psychology and Psychiatry 19, 1984-85, pp. 255-266.

----, The Absent Body. Chicago: University of Chicago Press, 1990.

Lee, N.-I, Edmund Husserls Phänomenologie der Instinkte. Dordrecht: Kluwer, 1993.

Olivier, A., Being in Pain. Frankfurt/M: Peter Lang, 2007.

Ortega y Gasset, J., Man and People. English transl. by Willard R. Trask, London: Allen \& Unwin, 1957.

Scarry, E., The Body in Pain. New York: Oxford University Press, 1985.

Serrano de Haro, A., "Dolor y atención. Análisis fenomenológico", in A. Serrano de Haro (ed.), Cuerpo vivido, Madrid: Encuentro, 2010, pp. 123-161.

Stumpf, C., "Gefühl und Gefühlsempfindung", in Schriften zur Psychologie, Frankfurt: Peter Lang, 1997. 
Waldenfels, B. Bruchlinien der Erfahrung. Frankfurt M.: Suhrkamp, 2002.

Welton, D., "Soft, smooth hands: Husserl's phenomenology of the lived-body", in D. Welton (ed.), The Body; Classic and Contemporary Readings, Oxford: Blackwell, 1999, pp. 38-56. 